http://jmscr.igmpublication.org/home/ ISSN (e)-2347-176x ISSN (p) 2455-0450 crossref DOI: https://dx.doi.org/10.18535/jmscr/v9i5.15

\author{
Journal Of Medical Science And Clinical Research \\ IGM Publication \\ An official Publication of IGM Publication
}

\title{
Original Research Article \\ Estimation of prevalence and risk factors of latent tuberculosis among medical and non-medical students
}

Authors

\section{Manjunath BG ${ }^{1}$ MD, DM, Lokesh Kumar Lalwani ${ }^{2 *}$ DNB, Dhruva Chaudhry ${ }^{3}$ MD, DM ${ }^{\#}$ Sarita $^{4}$ MD, DM, Aditya Chaudhry ${ }^{5}$, Geetika ${ }^{6}$}

${ }^{1}$ Assistant Professor in Department of Pulmonary and Critical Care Medicine

${ }^{2}$ Assistant Professor in Department of Tuberculosis\& Respiratory Diseases

${ }^{3}$ Senior Professor in Department of Pulmonary and Critical Care Medicine, Post Graduate Institute of

Medical Sciences

${ }^{4}$ Consultant Department of Pulmonary Medicine, ${ }^{\#}$ Sunflag Hospital, Rohtak, India

${ }^{5}$ Assistant Professor, Department of Medicine, Kalpana Chawla Government Medical College

${ }^{6}$ Demonstrator, Department of Anatomy

*Corresponding Author

Dr Lokesh Kumar Lalwani

Assistant Professor, Department of Tuberculosis \& Respiratory Diseases, Post Graduate Institute of Medical Sciences, Rohtak (Haryana), India-124001

\begin{abstract}
Background \& Objective: Identification and treatment of latent-tuberculosis-infection (LTBI) has remained at backstage for long. This study looks at the effect of graded-increase in clinical exposure on incidence of LTBI in health-care students and their non-exposed peers.

Methods: It was a cross-sectional observational study including 817 students (medical and non-medical). A one-step tuberculin-skin-test (TST) was performed using Monteux-technique. A positive TST, induration of $\geq 10 \mathrm{~mm}$, was considered suggestive of LTBI. Prevalence of LTBI was recorded among students of successive years and comparisons were made, in the two groups, with demographic variables.

Results: Mean age of the study population was $20.83 \pm 1.86$ years. $73.19 \%$ students were from an urbanbackground and $67.68 \%$ were from high-income-group. In medical and nursing group $29.08 \%$ and $30.55 \%$ students had TST positivity as compared to $14.23 \%$ in engineering students. Over four-years, the percentage of medical and nursing students having positive-TST increased from $13 \%$ to $\geq 40 \%$ ( $p<0.05)$, but no such change was present among engineering students. Relative-risk of acquiring LTBI in medical profession was $\geq 2.1$ as compared to non-medical profession. There was a strong correlation of TSTpositivity with increasing clinical exposure in the form of medical/surgical postings even after excluding TST-positivity due to community exposure ( $p<0.01)$. There was no association of TST positivity with gender, residence, family income, parents education and occupation and BCG vaccination ( $p>0.05$ ).

Conclusion: In our study, a higher prevalence of latent tuberculosis infection was demonstrated among medical and nursing students as compared to engineering students. This data favours further studies on the role of heightened infection control practices and potential role of treating LTBI among healthcareworkers.
\end{abstract}

Keywords: Healthcare workers, Latent-tuberculosis-infection, Medical-students, Monteux-test, tuberculin skin test 


\section{Introduction}

Tuberculosis (TB) is one of the most dominating infectious diseases globally due to its extreme contagious nature. It is a treatable, communicable disease that has two states of infection: latent tuberculosis infection (LTBI) and active disease. One-third of the world's population is estimated to be infected with mycobacterium tuberculosis. It claims a high number of lives around the world, every year, despite progress in medical knowledge and management. ${ }^{1}$

The prevalence of LTBI in India ranges from 9$80 \%$ as per various studies. ${ }^{2-4}$ Detection and treatment of active, transmissible disease have been the highest priority for both clinicians and public health officials, but it is crucial to identify and treat LTBI if we aim to attain total control of TB. To this date, there are no national guidelines for screening or management of LTBI among nonimmunocompromised individuals in India. ${ }^{5}$

In low prevalence countries, treatment of LTBI can achieve up to $80-90 \%$ reduction in active TB. Despite this, in high prevalence countries like India LTBI treatment remains neglected because treatment of LTBI will increase the logistic and financial burden on health system.

Healthcare workers (HCWs) are at risk of acquiring TB from contact with infected patients they care-for. ${ }^{6}$ The first outbreak of multi-drug resistant (MDR) TB was thought to have started from a healthcare facility in South Africa. ${ }^{7}$ Testing of LTBI will make them more careful and adherent to infection control measures. ${ }^{8,9}$ The lifetime risk of developing active TB (in $\mathrm{HCW}$ with recent LTBI) is $10-20 \%$, this is reduced to half when LTBI directed therapy is provided. ${ }^{10}$

As per national guidelines, LTBI is treated in patients with immunosuppression or children with exposure to active tuberculosis patient. $^{11}$ Treatment of LTBI is likely to be beneficial in subjects with risk factors that increase the chance of developing active TB and high-risk groups like health care workers.

Medical students and nursing students are among the vulnerable group as they are exposed to patients in their clinical postings and optimum precautions are not commonly used. ${ }^{12}$ Also, it would be interesting to know the effect of increasing clinical exposure on the incidence of LTBI in them and what is the prevalence of LTBI in non-exposed population of same age group.

No study from India has compared the prevalence of LTBI among medical and non-medical students. In this observational case-control study, we compared the point prevalence of LTBI among medical students, nursing students and nonmedical (engineering students) in different years, to understand about the nosocomial spread of TB infection. It will provide baseline data as well as a cohort for longitudinal studies and may help administrators to plan strategies for the prevention of the nosocomial spread of airborne infections.

\section{Material and Methods}

It was a cross-sectional observational study carried out in the department of pulmonary and critical care medicine at a tertiary care hospital of northern India (Pt B.D.S PGIMS, Rohtak) from January 2014 to August 2015. 817 students of medical (MBBS- bachelor of medicine and bachelor of surgery), BSc nursing and engineering courses were recruited after informed consent. 306 students were from the medical group, 216 from the nursing group and 295 from the engineering group. Students with a previous or present history of tuberculosis and immune-compromised individuals were excluded from the study. A detailed medical history of all the students with information regarding previous BCG vaccination, potential TB exposure from the clinical postings, previous history of tuberculin testing and of previous TB assessment was obtained through a questionnaire. Along with this, information on the socio-demographic profile of the students was also taken into account. BMI of the students was also calculated.

Ethical clearance was obtained from institutional ethical committee. After obtaining above mentioned information, a tuberculin skin test (TST) was performed using the Monteux 
technique by an experienced professional. One unit $(0.1 \mathrm{ml})$ of $10 \mathrm{TU}$ (tuberculin units) of purified protein derivative (PPD) solution was administered by intradermal injection on the volar aspect of the forearm using a 27 gauge needle. A positive TST was defined as in duration of $\geq 10 \mathrm{~mm}$ in transverse diameter perpendicular to forearm. Subjects having positive TST were considered to have LTBI.

\section{Statistical Analysis}

At the end of the study, both univariate and multivariate analysis was done from the collected data. Comparison of two categorical variables was done by Chi-Square Test. Comparison of categorical and a continuous variable was done by Independent student t-test. Multivariate analysis was performed on variables which were found significant on univariate analysis using a binomial logistic regression to assess the independent effect of each variable in our study. The exclusion and inclusion of variables were based upon the univariate analysis. A ' $p$ ' value of less than 0.05 was taken as significant.

\section{Results}

Demographic profile of students is presented in table-I. Mean age of study population was $20.83 \pm 1.86$ years with the predominantly female gender. Only one-fourth of the students were from a rural background and majority $(73.19 \%)$ were from urban areas (supplementary- suppl table 1). Nearly two thirds $(67.68 \%)$ were from the highincome group, however, students of medical and engineering group had a higher income than the nursing group $(\mathrm{p}<0.001)$ (suppl table 2$)$. In comparison to mothers, more fathers were literate (89.48\% vs $99.03 \%$ ) (suppl table 3 and 4). Fathers of maximum subjects were either professionals or in a government job, most parents had teaching profession and only $3.18 \%$ fathers were unemployed (suppl table 5) whereas nearly twothirds of student's mothers were home-makers (suppl table 6).

Only $7.95 \%$ of students had outside hospital environment exposure. Among these only one student from the medical group knew sputum status of the contact (positive). On the other hand, only $4.28 \%$ of subjects had exposure in the hospital community with least exposure among engineering students. There was no statistically significant difference in clinical exposure among medical and nursing groups $(\mathrm{p}=0.97)$ but there was a significant difference when the medical and nursing group were compared with the engineering group $(p<0.05)$. Presence of $B C G$ scar, which was suggestive of BCG vaccination in childhood, did not differ in frequency among the three groups of students (table II). The TST positivity did not differ among the students according to the BCG vaccination status $(\mathrm{p}=$ 0.218) (suppl table 7).

In medical and nursing group total of $29.08 \%$ and $30.55 \%$, respectively, had TST positivity as compared to $14.23 \%$ of engineering students $(\mathrm{p}<0.05)$. A significantly higher number of medical and nursing students had TST positivity with increasing years of study in comparison to engineering students where the number was largely static ( $\mathrm{p}=0.001$ ) (figure 1 and suppl table 8)). Over a period of four years, the percentage of medical and nursing students having positive TST increased from $13 \%$ to more than $40 \% \quad(\mathrm{p}<0.05)$ but there was no such change among engineering students $(\mathrm{p}>0.05)$. On multivariate analysis also, there was a strong correlation of the medical profession with TST positivity $(p=0.021)$. The relative risk of having latent tuberculosis infection was 2.04 ( $\mathrm{p}<0.0001$ 95\% CI 1.47 to 2.84) among medical students versus engineering students. Similarly, the relative risk was 2.15 ( $\mathrm{p}<0.000195 \%$ CI 1.52 to 3.03 ) among nursing students versus engineering students. When both nursing and medical students were compared, in combination, with engineering students relative risk was still high [2.09 (p $<0.000195 \%$ CI 1.53 to 2.84 ).

In an exploratory analysis among medical students sub-group, it was also analysed weather the exposure to medical or surgical postings had any impact on positivity of TST. It was found that 
among students with positive TST, the number of medicine and surgery posting days were higher as compared to the students who had negative TST (103.8 days versus 88.79 days, $\mathrm{p}=0.014$ ).
Other post hoc analysis like comparison of TST positivity with family income and residence did not differ among the subgroups ( $\mathrm{p}>0.05$ ) (suppl table 9 and 10).

\section{Supplementary Appendix}

Table 1 Residence wise distribution of students

\begin{tabular}{|l|c|c|c|c|}
\hline Residence & $\begin{array}{c}\text { A. Medical } \\
\mathbf{n = 3 0 6}(\boldsymbol{\%})\end{array}$ & $\begin{array}{c}\text { B. Nursing } \\
\mathbf{n = 2 1 6}(\%)\end{array}$ & $\begin{array}{c}\text { C.Engineering } \\
\mathbf{n = 2 9 5}(\boldsymbol{\%})\end{array}$ & Total n=817(\%) \\
\hline Rural & $64(20.91 \%)$ & $92(42.59 \%)$ & $63(21.35 \%)$ & $219(26.80 \%)$ \\
\hline Urban & $242(79.08 \%)$ & $124(57.40 \%)$ & $232(78.64 \%)$ & $598(73.19 \%)$ \\
\hline
\end{tabular}

Table 2 Distribution of students according to the gross family income.

\begin{tabular}{|l|c|c|c|c|}
\hline \multicolumn{2}{|c|}{ Family income (INR)/month } & $\begin{array}{c}\text { A. Medical } \\
\text { n=306(\%) }\end{array}$ & $\begin{array}{c}\text { B. Nursing } \\
\mathbf{n = 2 1 6}(\%)\end{array}$ & $\begin{array}{c}\text { Engineering } \\
\mathbf{n = 2 9 5}(\%)\end{array}$ \\
\hline 1 & $<5000(\mathrm{EWS})$ & $4(1.30 \%)$ & $4(1.85 \%)$ & $9(3.05 \%)$ \\
\hline 2 & $5000-10000(\mathrm{LIG})$ & $9(2.94 \%)$ & $21(9.72 \%)$ & $6(2.03 \%)$ \\
\hline 3 & $10000-20000(\mathrm{MIG})$ & $25(8.16 \%)$ & $50(23.14 \%)$ & $26(8.81 \%)$ \\
\hline 4 & $>20000(\mathrm{HIG})$ & $229(74.83 \%)$ & $122(56.48 \%)$ & $202(68.47 \%)$ \\
\hline 5 & Non responders & $39(12.74 \%)$ & $19(8.79 \%)$ & $52(17.62 \%)$ \\
\hline
\end{tabular}

Table 3 Father's education-wise distribution of the students.

\begin{tabular}{|l|l|c|c|c|c|}
\hline \multicolumn{2}{|l|}{ Father's education } & $\begin{array}{c}\text { A. Medical } \\
\mathbf{n = 3 1 6}(\%)\end{array}$ & $\begin{array}{c}\text { B. Nursing } \\
\mathbf{n = 2 1 6}(\%)\end{array}$ & $\begin{array}{c}\text { Engineering } \\
\mathbf{n = 2 9 5}(\%)\end{array}$ & $\begin{array}{c}\text { Total } \\
\mathbf{n = 8 1 7}(\%)\end{array}$ \\
\hline 1 & No schooling & $4(1.30 \%)$ & $3(1.38 \%)$ & $1(0.33 \%)$ & $8(0.97 \%)$ \\
\hline 2 & Primary school & $8(2.61 \%)$ & $0(\%)$ & $9(3.05 \%)$ & $17(2.08 \%)$ \\
\hline 3 & High school & $10(3.26 \%)$ & $12(5.55 \%)$ & $15(5.08)$ & $37(4.52 \%)$ \\
\hline 4 & Class X completed & $38(12.41 \%)$ & $57(26.38 \%)$ & $33(11.18 \%)$ & $128(15.66 \%)$ \\
\hline 5 & Class XI \& XII & $46(15.03 \%)$ & $45(20.83 \%)$ & $59(20 \%)$ & $150(18.35 \%)$ \\
\hline 6 & Diploma/bachelor & $103(33.63 \%)$ & $82(37.96 \%)$ & $105(35.59 \%)$ & $290(35.49 \%)$ \\
\hline 7 & Masters & $96(31.37 \%)$ & $17(7.87 \%)$ & $72(24.40 \%)$ & $185(22.64 \%)$ \\
\hline 8 & Non responders & $1(0.32 \%)$ & $0(\%)$ & $1(0.33 \%)$ & $2(0.24 \%)$ \\
\hline
\end{tabular}

Table 4 Mother's education-wise distribution of the students

\begin{tabular}{|l|l|c|c|c|c|}
\hline \multicolumn{2}{|l|}{ Mother's education } & $\begin{array}{c}\text { A. Medical } \\
\text { n=306(\%) }\end{array}$ & $\begin{array}{c}\text { B. Nursing } \\
\text { n=216(\%) }\end{array}$ & $\begin{array}{c}\text { Engineering } \\
\mathbf{n = 2 9 5}(\%)\end{array}$ & $\begin{array}{c}\text { Total } \\
\mathbf{n}=\mathbf{8 1 7}(\%)\end{array}$ \\
\hline 1 & No schooling & $30(9.80 \%)$ & $37(17.12 \%)$ & $19(6.44 \%)$ & $86(10.52 \%)$ \\
\hline 2 & Primary school & $20(6.53 \%)$ & $24(11.11 \%)$ & $19(6.44 \%)$ & $63(7.71 \%)$ \\
\hline 3 & High school & $19(6.20 \%)$ & $15(6.94 \%)$ & $20(6.77 \%)$ & $54(6.60 \%)$ \\
\hline 4 & Class X completed & $55(17.97 \%)$ & $52(24.07 \%)$ & $50(16.94 \%)$ & $157(19.21 \%)$ \\
\hline 5 & Class XI \& XII & $43(14.05 \%)$ & $40(18.51 \%)$ & $67(22.71 \%)$ & $150(18.35 \%)$ \\
\hline 6 & Diploma/bachelor & $66(21.56 \%)$ & $27(12.5 \%)$ & $69(23.38 \%)$ & $162(19.82 \%)$ \\
\hline 7 & Masters & $73(23.83 \%)$ & $21(9.72 \%)$ & $51(17.28 \%)$ & $145(17.74 \%)$ \\
\hline 8 & Non responders & 0 & 0 & 0 & $0(\%)$ \\
\hline
\end{tabular}

Table 5 Father's education wise distribution of the students

\begin{tabular}{|c|c|c|c|c|c|}
\hline \multicolumn{2}{|c|}{ Father's occupation } & $\begin{array}{c}\text { A. Medical } \\
\text { n=306(\%) }\end{array}$ & $\begin{array}{c}\text { B. Nursing } \\
\text { n=216(\%) }\end{array}$ & $\begin{array}{c}\text { Engineering } \\
\text { n=295(\%) }\end{array}$ & $\begin{array}{c}\text { Total } \\
\text { n=817(\%) }\end{array}$ \\
\hline 1 & Professional/ Govt. job & $137(44.77 \%)$ & $68(31.48 \%)$ & $119(40.33 \%)$ & $324(39.65 \%)$ \\
\hline 2 & Skilled worker & $45(14.70 \%)$ & $19(8.79 \%)$ & $48(16.27 \%)$ & $112(13.70 \%)$ \\
\hline 3 & Shop/farm owner & $70(22.87 \%)$ & $45(20.83 \%)$ & $68(23.05 \%)$ & $183(22.39 \%)$ \\
\hline 4 & $\begin{array}{c}\text { Unskilled / manual } \\
\text { laborer }\end{array}$ & $7(2.28 \%)$ & $20(9.25 \%)$ & $14(4.74 \%)$ & $41(5.01 \%)$ \\
\hline 5 & Retired/pensioner & $18(5.88 \%)$ & $34(15.74 \%)$ & $19(6.44 \%)$ & $71(8.69 \%)$ \\
\hline 6 & Unemployed & $7(2.28 \%)$ & $14(6.48 \%)$ & $5(1.69 \%)$ & $26(3.18 \%)$ \\
\hline 7 & Non responders & $20(6.52 \%)$ & $9(4.16 \%)$ & $20(6.77 \%)$ & $49(5.99 \%)$ \\
\hline 8 & Not alive & $2(0.65 \%)$ & $7(3.24 \%)$ & $2(0.67 \%)$ & $11(1.34 \%)$ \\
\hline
\end{tabular}


Table 6 Mother's education wise distribution of the students.

\begin{tabular}{|c|c|c|c|c|c|}
\hline \multicolumn{2}{|c|}{ Mother's occupation } & $\begin{array}{c}\text { A. Medical } \\
\text { n=306(\%) }\end{array}$ & $\begin{array}{c}\text { B. Nursing } \\
\text { n=216(\%) }\end{array}$ & $\begin{array}{c}\text { Engineering } \\
\text { n=295(\%) }\end{array}$ & $\begin{array}{c}\text { Total } \\
\text { n=817(\%) }\end{array}$ \\
\hline 1 & Professional/ Govt. job & $63(20.58 \%)$ & $30(13.88 \%)$ & $48(16.27 \%)$ & $141(17.25 \%)$ \\
\hline 2 & Skilled worker & $19(6.20 \%)$ & $5(2.31 \%)$ & $25(8.47 \%)$ & $49(5.99 \%)$ \\
\hline 3 & Shop/farm owner & $12(3.92 \%)$ & $7(3.24 \%)$ & $18(6.10 \%)$ & $37(4.52 \%)$ \\
\hline 4 & $\begin{array}{c}\text { Unskilled / manual } \\
\text { laborer }\end{array}$ & $6(1.96 \%)$ & $6(2.77 \%)$ & $5(1.69 \%)$ & $17(2.08 \%)$ \\
\hline 5 & Retired/pensioner & $2(0.65 \%)$ & $0(\%)$ & $1(0.33 \%)$ & $3(0.36 \%)$ \\
\hline 6 & Housewife & $199(65.03 \%)$ & $164(75.92 \%)$ & $189(64.06 \%)$ & $552(67.56 \%)$ \\
\hline 7 & Not alive & $3(0.98 \%)$ & $4(1.85 \%)$ & $8(2.71 \%)$ & $15(1.83 \%)$ \\
\hline 8 & Non responders & $2(0.65 \%)$ & $0(\%)$ & $1(0.33 \%)$ & $3(0.36 \%)$ \\
\hline
\end{tabular}

Table 7 Tuberculin sensitivity test positivity with BCG vaccination status

\begin{tabular}{|l|c|c|c|c|c|}
\hline & $\begin{array}{c}\text { Scar } \\
\text { absent }\end{array}$ & $\begin{array}{c}\text { Tuberculin sensitivity } \\
\text { test positive } \\
\mathbf{n}(\%)\end{array}$ & $\begin{array}{c}\text { Scar } \\
\text { present }\end{array}$ & $\begin{array}{c}\text { Tuberculin sensitivity } \\
\text { test positive } \\
\mathbf{n}(\%)\end{array}$ & $\begin{array}{c}\text { Statistical } \\
\text { significance }\end{array}$ \\
\hline MBBS & 42 & $9(21.42 \%)$ & 264 & $80(30.30 \%)$ & \multirow{2}{*}{$\mathrm{p}=0.218$} \\
\hline Nursing & 35 & $12(34.28 \%)$ & 181 & $54(29.83 \%)$ & \\
\hline Engineering & 60 & $6(10 \%)$ & 235 & $36(15.31 \%)$ & \\
\hline
\end{tabular}

Table 8 Tuberculin sensitivity test positivity in each year of college.

\begin{tabular}{|l|c|c|c|}
\hline Year of admission & $\begin{array}{c}\text { Medical } \\
\mathbf{n}(\%)\end{array}$ & $\begin{array}{c}\text { Nursing } \\
\mathbf{n}(\%)\end{array}$ & $\begin{array}{c}\text { Engineering } \\
\mathbf{n}(\%)\end{array}$ \\
\hline $2014\left(1^{\text {st }}\right)$ & $11 / 83(13.25 \%)$ & $7 / 53(13.20 \%)$ & $9 / 64(14.06 \%)$ \\
\hline $2013\left(2^{\text {nd }}\right)$ & $18 / 70(25.71 \%)$ & $16 / 55(29.09 \%)$ & $10 / 74(13.51 \%)$ \\
\hline $2012\left(3^{\text {rd }}\right)$ & $26 / 72(36.11 \%)$ & $20 / 55(36.36 \%)$ & $13 / 90(14.44 \%)$ \\
\hline $2011\left(4^{\text {th }}\right)$ & $34 / 81(41.97 \%)$ & $23 / 53(43.39 \%)$ & $10 / 67(14.92 \%)$ \\
\hline Total & $89 / 306(29.08 \%)$ & $66 / 216(30.55 \%)$ & $42 / 295(14.23 \%)$ \\
\hline $\begin{array}{l}\text { Statistical } \\
\text { significance (linear) }\end{array}$ & $\mathrm{p}=0.001$ & $\mathrm{p}=0.050$ & $\mathrm{p}=0.996$ \\
\hline
\end{tabular}

Table 9 Tuberculin sensitivity test positivity according to the residence.

\begin{tabular}{|l|c|c|c|c|}
\hline & \multicolumn{2}{|c|}{ Rural } & \multicolumn{2}{c|}{ Urban } \\
\hline & Total & Positive & Total & Positive \\
\hline MBBS & 64 & $13(20.31 \%)$ & 242 & $76(31.40 \%)$ \\
\hline Nursing & 92 & $35(38.04 \%)$ & 124 & $31(25 \%)$ \\
\hline Engineering & 63 & $7(11.11 \%)$ & 232 & $35(15.08 \%)$ \\
\hline
\end{tabular}

Table 10 Tuberculin sensitivity test positivity and its comparison with family income.

\begin{tabular}{|c|c|c|c|c|c|c|c|}
\hline \multirow{2}{*}{\multicolumn{2}{|c|}{$\begin{array}{l}\text { Family income (INR)/ } \\
\text { month }\end{array}$}} & \multicolumn{2}{|c|}{ MBBS } & \multicolumn{2}{|c|}{ Nursing } & \multicolumn{2}{|c|}{ Engineering } \\
\hline & & Total & Positive & Total & Positive & Total & Positive \\
\hline 1 & $<5000($ EWS $)$ & 4 & $1(25 \%)$ & 4 & $1(25 \%)$ & 9 & $0(\%)$ \\
\hline 2 & $\begin{array}{l}5000-10000 \\
\text { (LIG) }\end{array}$ & 9 & $2(22.22 \%)$ & 21 & $7(33.33 \%)$ & 6 & $1(16.66 \%)$ \\
\hline 3 & $\begin{array}{c}10000-20000 \\
(\mathrm{MIG})\end{array}$ & 25 & $8(32 \%)$ & 50 & $16(32 \%)$ & 26 & $8(30.76 \%)$ \\
\hline 4 & $>20000(\mathrm{HIG})$ & 229 & $69(30.13 \%)$ & 122 & $\begin{array}{c}36(29.50 \% \\
)\end{array}$ & 202 & $28(13.86 \%)$ \\
\hline 5 & Others & 39 & $9(23 \%)$ & 19 & $6(31.57 \%)$ & 52 & $5(9.61 \%)$ \\
\hline
\end{tabular}


Table I: Demographic profile of students. ${ }^{*}$ Community exposure outside the hospital environment was described as exposure at home or neighborhood and inside hospital exposure was defined as exposure through a classmate, roommate in hostel or any staff member working in the hospital.

\begin{tabular}{|l|c|c|c|c|}
\hline & A. Medical (n-306) & B. Nursing (n-216) & C. Engineering (n-295) & $p$ value \\
\hline Age (yr.)(Mean \pm SD) & $21.0 \pm 1.85$ & $20.66 \pm 1.38$ & $20.78 \pm 2.15$ & 0.101 \\
\hline Gender:Male & $140(45.75 \%)$ & $0(0.00 \%)$ & $243(82.37 \%)$ & \\
Female & $166(54.24 \%)$ & $216(100 \%)$ & $52(17.62 \%)$ & \\
\hline Community exposure*: & & & & AvsB=0.97 \\
Outside hospital & $31(10.13 \%)$ & $23(10.64 \%)$ & $11(3.72 \%)$ & AvsC $=0.01$ \\
Inside hospital & $20(6.53 \%)$ & $15(6.94 \%)$ & 0 & BvsC=0.01 \\
\hline
\end{tabular}

Table II: Frequency of presence or absence of BCG scar in medical (A), nursing (B) and engineering (c) groups.

\begin{tabular}{|l|c|c|c|}
\hline Course & Presence of BCG scar- n (\%) & Absence of BCG scar- $\mathrm{n}(\%)$ & $p$ value \\
\hline Medical (A) & $264(86.24 \%)$ & $42(15.9 \%)$ & AvsB=0.055 \\
\hline Nursing (B) & $181(83.79 \%)$ & $35(16.20 \%)$ & AvsC $=0.055$ \\
\hline Engineering (C) & $235(79.66 \%)$ & $60(20.33 \%)$ & BvsC $=0.055$ \\
\hline
\end{tabular}

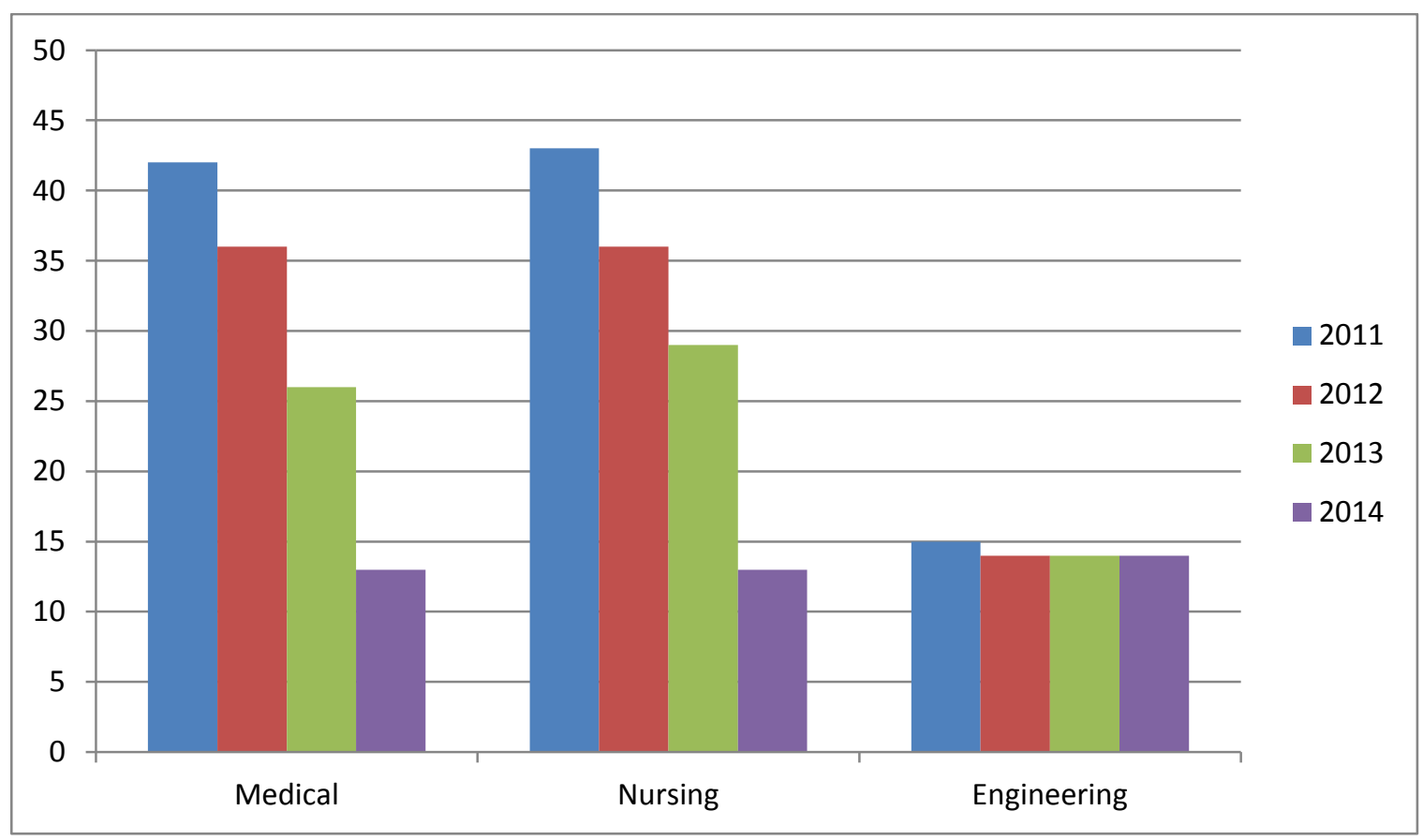

Figure 1- TST positivity with an increasing year of study

\section{Discussion}

LTBI is an inactive clinical state, defined by immunological evidence of $M$. tuberculosis infection either by positive TST or positive IGRA accompanied by an absence of clinical and radiographic evidence of active TB. ${ }^{11}$ Medical \& nursing students, nurses, staff members, contacts of TB patients and immunocompromised individuals are at high risk of developing LTBI.

IGRA is more specific than TST as it has no cross-reactivity with BCG vaccination and non- tuberculous mycobacteria, but measured values of IGRA are highly dynamic. Pai et al. $^{3}$ and Demkow et al. ${ }^{13}$ found a good correlation between TST and IGRA. WHO guidelines recommend the use of tuberculin skin test in place of IGRA in low-income and middle-income countries. ${ }^{11}$

Various studies have evaluated different strengths of PPD for TST. In a study by Rhonda et al. ${ }^{14}$ it was found that reaction to $10 \mathrm{TU}$ was more significant by $1.5 \mathrm{~mm}$ in comparison to 5TU. Also, we used a single-step TST, as there is evidence of 
a significant decrease in response when TST is done repeatedly (Behnazet al. ${ }^{15}$ ).

In our study we found that there was a significant correlation between TST positivity with increasing age in medical and nursing students $(p<0.05)$ suggesting a cumulative probability of TB exposure with increasing age. This factor was not influenced by gender or other variables, as has been described in previous studies by Paolo Durando et al. ${ }^{16}$ and Abbas et al. ${ }^{17}$

There was no association of TST positivity with residence $(\mathrm{p}=0.661)$ as most of the study subjects belonged to the urban region. Similarly, there was no association of TST positivity with parents income or education $(\mathrm{p}>0.05)$. Sumit Jethani found that tuberculosis was more common among low socioeconomic status and large families. ${ }^{18}$ However, as most of the students in our cohort belonged to upper socioeconomic status, this factor could not have played any significant role. It also suggests that TST positivity depends on multiple factors like exposure, sputum status of the contact, immune status of the host and not merely on the socioeconomic status of the subject of interest alone.

We found that with increasing BMI, there was less TST positivity. In contrast, Christopher et al. ${ }^{4}$ found a positive relationship of TST positivity with BMI, explained by blunted hypersensitivity reaction in low BMI students due to less immune reaction whereas $P e r u^{19}$ found false-negative TST in individuals with lower body protein proportion, implying that protein malnutrition causes tuberculin-specific anergy. This discrepancy can be due to two main reasons. First, such level of malnutrition did not exist in our study population which could have caused blunted immunity. Secondarily, the age of our population was still younger than those in previous studies. In addition extremes of BMI did not exist in our cohort.

Madhukar Pai et al. showed 40\% TST positivity among health care workers who had community exposure. ${ }^{3}$ Similarly, in the present study, $46.15 \%$ of students who had community exposure and $40 \%$ of students who had exposure in the hospital community were TST positive which is consistent with previous studies. This data suggests that the history of community exposure to tuberculosis is a high risk for LTBI $(\mathrm{p}<0.01)$.

$83.47 \%$ of students in our study had BCG scar present due to national vaccination policy of India. BCG vaccination had little impact on TST positivity. Ruffino Nett et al. ${ }^{20}$ reported that $64.8 \%$ of BCG-vaccinated students were still nonreactors to TST even when BCG was administered two years back. Recent tuberculin surveys ${ }^{21}$ from India involving more than one lakh children had also shown that BCG vaccination does not influence the annual risk of infection. A study done by Teixeira et al. ${ }^{22}$ showed that BCG scar was not always associated with positive TST. These findings endorse the fact that TST positivity can be taken as evidence of LTBI even in countries like India, where BCG vaccination is universal.

Most important finding of our study was that we found a strong association of increasing clinical exposure with TST positivity among medical students even after excluding students with history of community exposure $(\mathrm{p}<0.05)$, in addition there was a significantly higher TST positivity in final year than the firstyear $(p<0.05)$ students of nursing. The probable reason behind this finding was increasing exposure to patients after their clinical postings from the second year. The prevalence of LTBI among MBBS students was $13.25 \%$ in the first year, $25.71 \%$ in the second year, $36.11 \%$ in the third year and $41.97 \%$ in the final year. In nursing students it was $13.20 \%$, $29.09 \%, 36.36 \%, 43.39 \%$ in respective years. Whereas, there is no such trend seen in their contemporaries from engineering cohort.

Madhukar Pai ${ }^{3}$ showed that $41 \%$ of health care workers, including medical students, were suffering from LTBI as determined by TST positivity. According to Mugerwa et al. ${ }^{23}$, the prevalence of TB infection was $44.8 \%$ among medical students and $35.2 \%$ among veterinary students. A higher prevalence among medical students was due to increasing clinical exposure. Silva et al. ${ }^{24}$ found increasing prevalence from 
$4.2 \%$ to $16.2 \%$ with an increasing year of study among medical students and it was only $4.2 \%$ to $4.4 \%$ among engineering students. In a prospective study among nursing students by Christopher et al. ${ }^{25}$ concluded that, annual risk of TB infection measured by TST conversion was $7.8 \%$, which was 5-folds higher than the national average. A study done in Peru ${ }^{26}$ showed that TST conversion risk was $61 \%$ and $51 \%$ higher among nursing and medical students respectively, compared to non-clinical careers. Similarly, in our study, risk of having LTBI among medical and nursing group was more than double when compared with engineering group. TST positivity was also significantly associated with medicine and surgery postings. Median days of posting in TST positive students were 103.80 days as compared to 88.79 days in TST negative students. Our findings and previous data concludes that the working environment is a significant determinant of TST positivity especially for healthcare workers $(\mathrm{p}<0.01)$.

Safety Profile- None of the students, who took the test, showed locoregional or systemic allergic reactions. Some students complained of itching at the site of injection, which was self-limiting.

There are few merits of the study, like comparison with a population of students who nearly do not have any exposure (engineering students). Also, we compared the TST positivity across several batches in succession to implicate the effect of clinical postings longitudinally. Apart from the huge population of the students which were included in the study, single step-TST with a $10 \mathrm{~mm}$ cut off was another significant merit of our study. A few limitations of our study were, not knowing the actual protective gears used by the students in their clinical postings for infection control. Also, a detailed history of exposures during clinical posting could have been recorded.

\section{Conclusion}

In this study, we found that medical students, both from nursing as well as MBBS, have a high probability of developing LTBI. This correlates with the extent of clinical posting exposure as well. Such high positivity and a known fact, of developing active tuberculosis from LTBI, should be taken seriously by the policy-makers and should prompt an LTBI directed program among healthcare workers. Also, the impact of strict infection control policies like masks, hand hygiene, isolations, should be studied at an individual level of clinical exposures.

Financial support and sponsorship: This research received a grant from RNTCP (Revised National Tuberculosis Control Program).

Conflict of Interest: None to declare Institutional review Board approval

This study was approved by the institutional review board of Pt. BDS Post graduate institute of medical sciences (vide letter number IRB/15/98) performed in accordance with the principles of the Declaration of the Helsinki. Written informed consents were obtained.

Acknowledgement: None

\section{Manuscript Approval Statement:}

The final submitted manuscript has been read and approved by all authors.

\section{References}

1. World Health O. Global tuberculosis report 2015. 20th ed ed. Geneva: World Health Organization; 20152015.

2. Joshi R, Reingold AL, Menzies D, Pai M. Tuberculosis among health-care workers in low- and middle-income countries: a systematic review. PLoS Med. 2006;3(12): e494.

3. Pai M, Gokhale K, Joshi R, Dogra S, Kalantri S, Mendiratta DK, et al. Mycobacterium tuberculosis infection in health care workers in rural India: comparison of a whole-blood interferon gamma assay with tuberculin skin testing. Jama. 2005;293(22):2746-55.

4. Christopher DJ, Daley P, Armstrong L, James P, Gupta R, Premkumar B, et al. Tuberculosis infection among young 
nursing trainees in South India. PLoS One. 2010;5(4):e10408.

5. Agarwal U, Mathur D, Mathur D, Besarwal R, Agarwal P. Ear sign. Lung India. 2005;22(4):105-6.

6. Pai M, Christopher DJ. Protecting young healthcare trainees from tuberculosis: can we overcome apathy? Natl Med J India. 2011;24(4):198-200.

7. Ben Amor Y, Nemser B, Singh A, Sankin A, Schluger N. Underreported threat of multidrug-resistant tuberculosis in Africa. Emerg Infect Dis. 2008;14(9):1345-52.

8. Blumberg HM, Watkins DL, Berschling JD, Antle A, Moore P, White N, et al. Preventing the nosocomial transmission of tuberculosis. Ann Intern Med. 1995;122(9):658-63.

9. Jelip J, Mathew GG, Yusin T, Dony JF, Singh N, Ashaari M, et al. Risk factors of tuberculosis among health care workers in Sabah, Malaysia. Tuberculosis (Edinb). 2004;84(1-2):19-23.

10. Torres Costa J, Silva R, Sá R, Cardoso MJ, Nienhaus A. Results of five-year systematic screening for latent tuberculosis infection in healthcare workers in Portugal. Journal of Occupational Medicine and Toxicology. 2010;5(1):22.

11. Getahun H, Matteelli A, Abubakar I, Aziz MA, Baddeley A, Barreira D, et al. Management of latent Mycobacterium tuberculosis infection: WHO guidelines for low tuberculosis burden countries. Eur Respir J. 2015;46(6):1563-76.

12. Singla N, Sharma PP, Jain RC. Awareness about tuberculosis among nurses working in a tuberculosis hospital and in a general hospital in Delhi, India. Int $\mathbf{J}$ Tuberc Lung Dis. 1998;2(12):1005-10.

13. Demkow U, Broniarek-Samson B, Filewska M, Lewandowska K, Maciejewski J, Zycinska K, et al. Prevalence of latent tuberculosis infection in health care workers in Poland assessed by interferon-gamma whole blood and tuberculin skin tests. J Physiol Pharmacol. 2008;59 Suppl 6:209-17.

14. Stuart RL, Bennett N, Forbes A, Grayson ML. A paired comparison of tuberculin skin test results in health care workers using $5 \mathrm{TU}$ and $10 \mathrm{TU}$ tuberculin. Thorax. 2000;55(8):693-5.

15. Behnaz F, Mohammadzadeh M, Mohammadzade G. Tuberculin skin tests among medical students at risk for nosocomial transmission of Mycobacterium tuberculosis in Yazd, Iran. International Journal of Infection Control. 2013;9.

16. Durando P, Sotgiu G, Spigno F, Piccinini M, Mazzarello G, Viscoli C, et al. Latent tuberculosis infection and associated risk factors among undergraduate healthcare students in Italy: a cross-sectional study. BMC Infectious Diseases. 2013;13(1):443.

17. Abbas MA, AlHamdan NA, Fiala LA, AlEnezy AK, AlQahtani MS. Prevalence of latent TB among health care workers in four major tertiary care hospitals in Riyadh, Saudi Arabia. J Egypt Public Health Assoc. 2010;85(1-2):61-71.

18. Kakkar R. Socio- Demographic Profile of Tuberculosis patient: A hospital based study at Dehradun. National Journal of Community Medicine. 2014;5:6-9.

19. Pelly TF, Santillan CF, Gilman RH, Cabrera LZ, Garcia E, Vidal C, et al. Tuberculosis skin testing, anergy and protein malnutrition in Peru. Int $\mathrm{J}$ Tuberc Lung Dis. 2005;9(9):977-84.

20. Dias MHdP, Hayashi A. Prova tuberculínica, BCG oral e infecção tuberculosa em crianças menores de 5 anos. Revista de Saúde Pública. 1978;12:443-54.

21. Chadha VK, Jagannatha PS, Kumar P. Can BCG-vaccinated children be included in tuberculin surveys to estimate the annual 
risk of tuberculous infection in India? Int $\mathbf{J}$

Tuberc Lung Dis. 2004;8(12):1437-42.

22. Teixeira EG, Menzies D, Comstock GW, Cunha AJ, Kritski AL, Soares LC, et al. Latent tuberculosis infection among undergraduate medical students in Rio de Janeiro State, Brazil. Int J Tuberc Lung Dis. 2005;9(8):841-7.

23. Mugerwa H, Byarugaba DK, Mpooya S, Miremba P, Kalyango JN, Karamagi C, et al. High Prevalence of tuberculosis infection among medical students in Makerere University, Kampala: results of a cross sectional study. Archives of Public Health. 2013;71(1):7.

24. Silva VM, Cunha AJ, Oliveira JR, Figueira MM, Nunes ZB, DeRiemer K, et al. Medical students at risk of nosocomial transmission of Mycobacterium tuberculosis. Int $\mathrm{J}$ Tuberc Lung Dis. 2000;4(5):420-6.

25. Christopher DJ, James P, Daley P, Armstrong L, Isaac BT, Thangakunam B, et al. High annual risk of tuberculosis infection among nursing students in South India: a cohort study. PLoS One. 2011;6(10):e26199.

26. Pérez-Lu JE, Cárcamo CP, García PJ, Bussalleu A, Bernabé-Ortiz A. Tuberculin skin test conversion among health sciences students: a retrospective cohort study. Tuberculosis (Edinb). 2013;93(2):257-62. 